\title{
WHETHER GLOBALIZATION IN FORM OF FDI ENHANCES NATIONAL WEALTH: EMPIRICAL EVIDENCE FROM LITHUANIA
}

\author{
Manuela Tvaronavičiené $\dot{e}^{1}$, Kristina Kalašinskaitè ${ }^{2}$ \\ Vilnius Gediminas Technical University, Saulètekio al. 11, 10223 Vilnius, Lithuania \\ E-mails: ${ }^{1}$ manuela@vgtu.lt; ${ }^{2}$ kristina.kalasinskaite@vgtu.lt \\ Received 23 February 2009; accepted 10 January 2010
}

\begin{abstract}
Presented paper aims to suggest theoretical framework, application of which would allow indicating if foreign direct investment (FDI) facilitates or hinders economic development of host country economy. Central ideas elaborated in the article are as follows. The first, necessity of cost-benefit analysis of FDI inflow is emphasized. As state policy favourable for foreign capital means costs, instrument for benefit estimation is required. Neoclassical and industrial organization theories are being employed for FDI effects evaluation purpose. Assumption about changing effect of FDI after medium-term period of 6-7 year passes has been raised and tested. Data of Lithuanian manufacturing branch and its three main comprising manufacturing sectors for the 1996-2007 period have been employed. Results of application of elaborated theoretical framework lead to corollary about different impact of FDI on various sectors of economy and high probability of diminishing positive initial impact after medium-term time span passes.
\end{abstract}

Keywords: FDI, economic growth, Lithuania, theoretical framework.

Reference to this paper should be made as follows: Tvaronavičienè, M; Kalašinskaitè, K. 2010. Whether globalization in form of FDI enhances national wealth: empirical evidence from Lithuania, Journal of Business Economics and Management 11(1): 5-19.

\section{Introduction}

Foreign direct investment (FDI) almost unanimously is seen as driving force of economic growth. Such belief is especially viable among politicians of developing countries, striving to accelerate economic and technological development, to enhance competitiveness of host economies. Unquestioning of FDI impact, in some cases, leads to unforeseen consequences, which not always comply with expectations. Lack of deeper FDI phenomenon consideration triggers risk of negative cost-benefit results of globalization for FDI recipient country. Cost in this case embraces various tax exemptions and privileges provided by host country to foreign origin proprietorship in local enterprises. Benefits, in their turn, are much more implicit, and hard to estimate; as alternative case, when the same enterprises would be run by local capital, remain a hypothetical case.

In order to trace effects of foreign ownership on capital recipient country, theoretical framework has to be developed. FDI does not comprise homogeneous theory as 
is connected to multifaceted aspects of interrelated fields, such as, economic growth, international economics, international strategic management and industrial organization. Interdisciplinary nature of FDI conditions variety approaches towards FDI, what, in its turn, does not fit into one consistent track. Authors, as a rule, elaborate chosen topic into different directions. Such range of scientific interests could be understood and justified after getting acquainted with a variety of foreign proprietorship emerging forms, which, according to formal agreement, later is being statistically recorded as inward (respective to host country) FDI.

\section{Foreign proprietorship forms considered as foreign direct investment}

In order to discuss theoretical framework of FDI cost-benefit analysis for host country, and answer the question, if FDI enhances national wealth, clear understanding of FDI phenomenon, at first, is required. Frequently foreign direct investment is understood as capital inflows of foreign capital, i.e. coincided with financial capital, put into host country enterprise. Alas, such perception is incomplete; it does not embrace other legislative forms of FDI entrance, which cannot provide additional capital in any form and still be considered as foreign direct investment. Foreign direct investment may appear not only through input of foreign capital, but, according to international agreement, FDI would be recorded in a case of purchase of stake of host country enterprise that is owned by residents of the investing country. Foreign direct investment implies full or partial acquiring of local enterprise, what leads to obtaining rights of considerably significant degree of control by the investor over the management of the enterprise. Conventionally, FDI is established when a foreign investor in local company owns 10 percent or more of the ordinary shares or voting power. If foreign investor owns share of authorized capital, which is lesser than 10 percent, such investment is considered as foreign portfolio investment (FPI). Hence, foreign investments are generally referred to investments made by individuals or enterprises that have their center of economic interest in an economy other than the economy in which they invest. As it was provided above, these international acquisitions of economic interests take two major forms: foreign direct investments and foreign portfolio investments (Goldstein, Assaf 2006). To generalize, there is a rather thin line between FDI and FPI. FDI embraces not only additional inflow of financial capital, but as well appears in case of enterprise ownership origin change. Ownership change, e.g. from local to foreign, not necessarily has to affect activity of local company. Despite this there is FPI, which is supposed to have other function than control in case of stake is being acquired; FDI as well does not mean automatic influence on management of FDI recipient company.

Interest in management usually is being expressed, when FDI takes the following forms: greenfield, mergers and acquisitions (M\&A), and joint ventures (Raff et al. 2009). Greenfield FDI is involved in establishing new production, distribution or other facilities in the host country. In the context of transition economies the term "brownfield FDI" is often used to describe situation, when a foreign investor formally acquires a private firm (Meyer, Saul 2001) or purchases it from government (Buckley, Casson 
1998; Tvaronavičienè, Kalašinskaitè 2007). In that case, origin of capital changes from local to foreign. Consequences of such change can have a very wide range; i.e. from negative, to non-existent or, what is usually expected, positive to company, industry, and, respectively welfare enhancing for a host country (Tvaronavičienė, Grybaitė 2007).

All listed above forms of FDI may be financed by different combination of financial sources. FDI may consist of equity capital (the foreign investor's purchases of shares in an enterprise home country), reinvested earnings (share of earnings not distributed as dividends by affiliates or remitted to the investor origin country, but rather reinvested in the host country) and loans comprising of short-term and long-term borrowings. Foreign direct investment statistically can be recorded as FDI flows or cumulative FDI. FDI flows represent yearly FDI and do not take into account other time periods, when FDI occurred. Another measurement, FDI stocks, represents the value of the share of the capital and reserves (including retained profits) attributable to the foreign enterprise, plus the net indebtedness of affiliates of the parent enterprise. To put it another way, FDI stocks could be perceived as accrued inflows. For analysis purposes, usually cumulative FDI measure, is being used, as FDI inflows, as a rule, are uneven and too insignificant if to compare to value added generated in industry and even more insignificant in the whole country's context.

Despite FDI stocks there is a more relevant measure of foreign proprietorship, in case of estimation of its effects on host country development, distinction between FDI flows and FDI stocks retains its importance for deeper understanding processes, which, actually, are conditioned by FDI flows.

To generalize, diversity of activities forms, which fall under definition of FDI and variety of ways to obtain stakes in local companies (direct input of financial means, reinvesting of profits, loans and buy-out) condition complicity of task to perform costbenefit analysis of FDI for host country. Superficially judging, host country performs the role of foreign capital recipient. As FDI sources are detailed, it becomes clear that foreign direct investment might not mean any financial investment for local company. Privatization, which is associated with transformation of state ownership to private one, in case of FDI can lose this core essence, e.g. as evidence from Lithuania verifies, in some cases local state capital was replaced by foreign state capital with specially devised conditions for avoiding competition in local market (Ginevičius, Tvaronavičienè 2004).

Studies devoted to FDI impact on development of transition countries suggest that positive effects are quite fragile and combined with widespread usage of tax holidays, subsidies and acquisition discounts, leave uncertainty about relation of direct effects and economic growth in these countries (Jensen 2006). State policies towards FDI as a rule are costly to host countries and not necessarily efficient (Durham, Benson 2004; Tvaronaviciene et al. 2009); therefore estimation of benefits conditioned by globalization processes remains the main scientific concern and issue to be tackled.

In order to construct theoretical framework letting to perform FDI cost-benefit analysis let us briefly overview germination of FDI theory. 


\section{Approaches towards plausible FDI effects}

At the end of the 50's FDI has been prevailingly explained within the framework of neoclassical theories (Buckley 2006). According to the theory capital moves from countries where the interest rate is low to those where the interest rate is higher. The theory assumes risk neutrality, absence of transaction costs and barriers. These assumptions do not correspond reality, and when risk, uncertainty and barriers to the movement of capital among nations are introduced, the theory loses its predictive ability.

Neoclassical trade theory, which assumes that trade patterns are determined by relative supplies of factors of production (e.g. skilled and unskilled labour, capital and natural resources) and/or by differences in tastes and technology, could not either explain why FDI in various forms take place (Hosseini 2005).

Hymer analyzed multinational enterprises and FDI focusing on strategic behaviour of firms, the structure of markets and their interactions on the basis of industrial organization theory, which includes a study of market imperfections. The theory was further extended by Kindleberger, and became known as Hymer-Kindleberger paradigm (Hosseini 2005). Adoption of complex approach towards FDI, and taking into account factors comprising a set of capital inflows or ownership share acquisitions in various economy sectors let to reveal controversial effects of separate FDI cases in Lithuania (Ginevičius, Tvaronavičienè 2004). Ability of foreign direct investors to repatriate capital and remit profits appeared to be a rather significant criterion by tackling certain industry (Ginevičius, Tvaronavičiene 2004). Those findings are consistent with conclusions of other authors (Leahy, Montagna 2000; Tarzi 2005), claiming that specific market structures in FDI receiving industries and forms of foreign capital entry condition, finally, positive or detrimental impact of globalization on separate economic sectors, which indirectly affects the whole local economy.

Attempts to combine firm and market structure level have been made by Japanese scientists Kojima and Ozawa and are known as The Kojima Hypothesis. According to authors, host country's industrial policies complement stimuli for FDI provided by market structures in particular industry (McClintock 1988).

In our research we adopt industrial organization approach, assuming that market structure and form of FDI entry, which in its turn reflects reaction to state policy, conditions positive or detrimental impact on industry development. Another, new in FDI scientific literature, assumption roots in decreasing-returns tendencies highlighted by the neoclassical growth model.

Notable, that some authors (e.g. Romer 1986, 1993), oppositely, model increasing returns of FDI through knowledge spillover, as, according to them, "idea gaps" between developed and developing economies exist, and those spillover effects (Borensztein et al. 1998) tend to growth as that gap shrinks. In current years, if to take into account globalization rate, claims about "idea gaps" appear to be not sufficiently grounded anymore. Other authors claim (e.g. Adekola et al. 2008; Tvaronavičienè, Degutis 2007), that organizational culture of foreign capital firms differs from local firms' culture and therefore foreign firms are more efficient. We stick to economic theories, and sup- 
port protagonists of diminishing returns approach. If FDI takes form of capital investments, then returns diminish as neoclassical growth model suggests; though it does not mean capital investments do not play an important role in contemporary economy (Tvaronavičius, Tvaronavičienė 2008). On the other hand, if FDI enters by acquiring local company's stake, then it is most likely, that after "spillovering", company being controlled by foreign capital would crowd local companies out of market or start to repatriate profits. Market structure here plays a crucial role, hence diminishing FDI returns obtain especially relevant context when considered through industrial organization theory lenses (Kottaridi 2005). Separate bulk of literature on relationships between FDI and bankruptcies of host country firms exist (e. g. Jensen 2006). Within framework of this paper we are not going to elaborate the mentioned aspect, just restrict ourselves to noticing existing ample empirical evidence for crowding in on locals. In those, listed above, cases diminishing of initial positive (if such indicated) impact would be considered as highly plausible. In order to test hypothesis of diminishing FDI effect on host economy industries, empirical research has to be performed. Before providing theoretical framework for such research, let us just notice that the results of numerous empirical studies are very heterogeneous (Tiiks 2007). Besides proofs of some negative impacts of FDI, the positive effects of FDI on economic growth were also claimed to be only transitory, i.e. not permanent (Kenen 2007; Tvaronavičienė, Kalašinskaitė 2007). Those opinions are consistent with our hypothesis of changing impact of FDI after mediumterm period of time span passes; phenomenon appearing as consistent pattern, despite an array of other economic growth drivers exists (Lapinskienè, Tvaronavičienè 2009).

We emphasize, that aim of this research is to provide a conceptual framework enabling evaluation of FDI impact on development of separately taken industries. Impact itself is understood like process, which is complex and changeable. We would try to reveal and summarize the cases of the changing FDI effect on economic development and to provide a quantitative assessment of globalization effect, which takes form of FDI. Outcomes are being estimated looking from the point of individual economic sectors, which naturally affect the entire Lithuanian economy development. The period of 1996-2007 serves as time span being targeted.

\section{Assessment of the impact of FDI on main economic sectors' expansion}

Adopted theoretical assumptions about different impact of FDI on different sectors of economy depending on their market structure and hypothesis of changing effects of FDI has led us to the theoretical framework, which could be presented by the following sequential steps.

1. Strength of linear relationship between values added generated in main economic activities and FDI, directed to respective economic activities is being determined. For that purpose statistical data of the 11-year period, i.e. for 1996-2007 are being used. Expected outcome is indication of different impacts of globalization on development of main branches of local, in our case Lithuanian, economy. Those branches, which develop more as a result of globalization, are being considered as enhancing national wealth. 
2. Manufacturing sector, towards which significant share of overall FDI, was channelled is being scrutinized, i.e. strength of linear relationship for sector comprising economic activities for the 11-year period ( 1996-2007) and two shorter periods, i.e. 1996-2002 and 2002-2007, is being tested.

3 . In case, strength of relationships calculated for 11 years (1996-2007) and for comprising 7-year (1996-2007) and 6-year (2002-2007) periods change, non-linear relationship for longer, i.e. the 11-year period is being indicated. Assumption is that in case of significant change of correlation coefficients values during the first and the second comprising time periods, non-linear equation for the whole 1996-2002 time period should considerably differ from linear expression. If the assumption is verified, we would consider non-linear function for identification of plausible fluctuations of FDI impact during 6-7 (medium-term)-year period.

The first step of analysis attempts to identify FDI impact on the main branches of economy by using correlation-regression analysis; the period for analysis embraces years 1996-2007 (initial data and detailed results of quantitative analysis are presented in Appendix 1). To generalize, relationships between share of GDP generated (mill LTL) in main branches of Lithuanian economy and share of FDI (mill LTL) directed into same branches are as follows. Correlation coefficient between agricultural sector and FDI channeled to agriculture is 0.49 (weak relationship), correlation coefficient between the same variables in manufacturing is 0.98 , in construction and services 0.96 and 0.98 , respectively. In case of not going into further analysis, suggested corollary would claim existence of positive relationship between FDI and sector growth, which meant FDI enhances growth almost in all main sectors of economics.

Following elaborated framework for further scrutinizing we choose manufacturing branch, which among neighbouring Latvia and Estonia attracted the highest share of FDI (Kalašinskaite 2009). Manufacturing branch is being comprised of the following main economic activities: manufacturing sector of food products, manufacturing sector of textile, manufacturing sector of refined petroleum and supply of electricity, gas and water. The relationships in the latter sector will not be considered within framework of this research due to high level of state regulation, which, to our mind, distort GDP and FDI national wealth enhancing or deteriorating relationships.

Quantitative evaluation results (correlation coefficients) of relationships between GDP and FDI in each mentioned manufacturing sector, differ across sectors and different length time spans. E.g., if for the industrial manufacturing branch the value of correlation coefficient equals 0.98 , respective correlation coefficients for comprising activities vary between 0.529 and 0.843 for the same 11 -year period (Table 1). In order to test if character of relationship between sector FDI and GDP changes, correlation coefficients for shorter time periods were indicated. It appeared, that when considered 11-year period is being split into two medium-term periods, character of relationship changes significantly, e.g. in manufacturing sector correlation coefficient of 0.529 for the 1996-2007 period changes to 0.260 for 1996-2002 and to -0.297 for the 2002-2007 period; correlation coefficient in manufacturing sector of textile changes from 0.843 to 0.909 and -0.735 , when considered time period is being split into two. In manufacturing 
Table 1. Juxtaposition of correlation coefficients of linear relationship between industrial sector GDP and sector FDI for the 1996-2007 period and medium-term (split) periods

\begin{tabular}{|c|c|c|c|c|c|}
\hline \multicolumn{2}{|c|}{$\begin{array}{l}\text { Manufacturing sector } \\
\text { of food products } \\
\text { (years 1996-2007) }\end{array}$} & \multicolumn{2}{|c|}{$\begin{array}{l}\text { Manufacturing sector } \\
\text { of textile } \\
\text { (years 1996-2007) }\end{array}$} & \multicolumn{2}{|c|}{$\begin{array}{l}\text { Manufacturing sector } \\
\text { of refined petroleum } \\
\text { (years 1996-2007) }\end{array}$} \\
\hline \multicolumn{2}{|c|}{0.529} & \multicolumn{2}{|c|}{0.843} & \multicolumn{2}{|c|}{0.701} \\
\hline (years & (years & (years & (years & (years & (years \\
\hline 1996-2002) & $2002-2007)$ & 1996-2002) & $2002-2007)$ & 1996-2002) & $2002-2007)$ \\
\hline 0.260 & -0.297 & 0.909 & -0.735 & 0.295 & 0.480 \\
\hline
\end{tabular}

Source: Kalašinskaitė 2009: 104-111.

sector of refined petroleum correlation coefficient of 0.701 changes to 0.295 and 0.480 respectively (Table 1). Initial data and detailed results of quantitative analysis are presented in Appendix 2 (Appendix 2.1, 2.2, 2.3 indicate data and correlation coefficients for indicated above time periods used for analysis purposes).

Corollary, which can be drawn, is that assumption about changing impact of FDI on economic development of recipient sector has been verified. The idea we offer is tentative, and we have no final proof of its validity, nor is such proof likely to become available. Anyway, admitting that the process is highly complex and changeable, we believe it is important to develop conceptual framework letting to indicate possible cases of such FDI impact change.

As it was indicated above, in further analysis we admit, that in case of significant change of value of correlation coefficients during the first and the second periods, into which considered 11-year time span is split, non-linear equation for the whole 1996-2002 time period could be used for prediction about a possible change in character (strength or direction) of relationship between GDP and FDI after 6-7 years have passed. We make an assumption that in case non-linear function considerably differs from linear expression, change of FDI impact on development of FDI- recipient-sector is more plausible. The non-linear (or curvilinear) relation was calculated with "Mathematics" computer software. On the basis of the software-produced relationship between the gross domestic product (GDP) and FDI, the assessment of FDI influence character on development of considered economic activities is being obtained (Figs. 1, 2, 3).

Non-linear relationship obtained for food product manufacturing sector resembles linear relationship. According to assumption raised, it would indicate that character of relationship between sector GDP and sector FDI does not change principally after medium-term period (in our case 6-7 years) passes. According to our calculus, correlation coefficient of linear relationship for 1996-2007 time period was 0.529 (Table 1, Appendix 3.1); while for shorter 1996-2002 and 2002-2007 periods it appeared to be 0,260 and, $-0,297$ respectively (Table 1, Appendixes 3.2 and 3.3). Despite that correlation coefficients changed, we need to take into account that values indicated appeared to be of insignificant strength. Hence, within our theoretical framework, we can conclude, that assumption we raised was verified, i.e. in case non-linear relationship resembles linear 


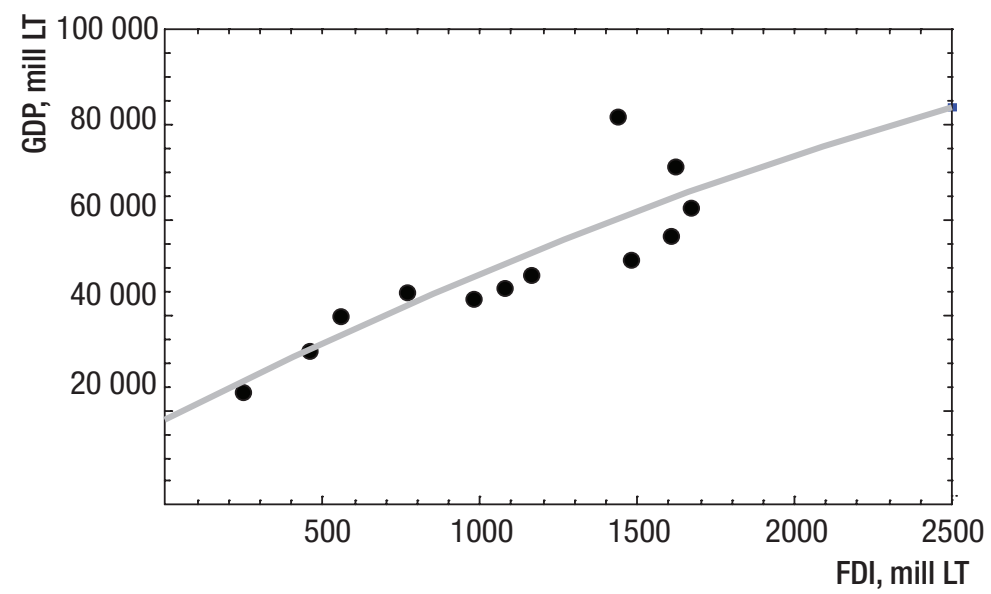

Fig. 1. Graphical view of non-linear relationship between GDP in manufacturing sector of food products and FDI directed into the economic activity

(next the nearest option is linear relationship)

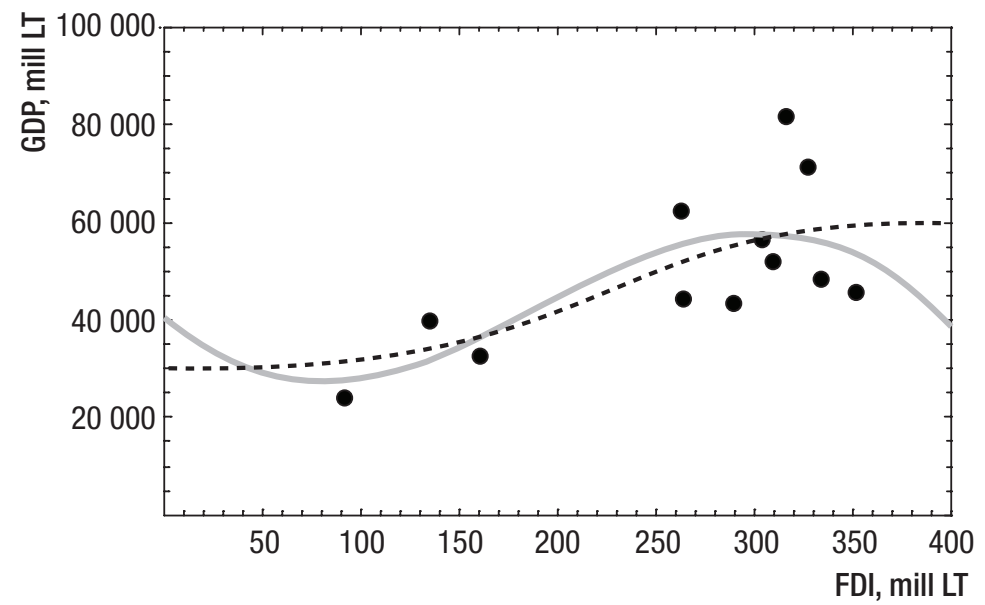

Fig. 2. Graphical view of non-linear relationship between GDP in manufacturing sector of textile and FDI directed into the economic activity

(two the nearest options presented)

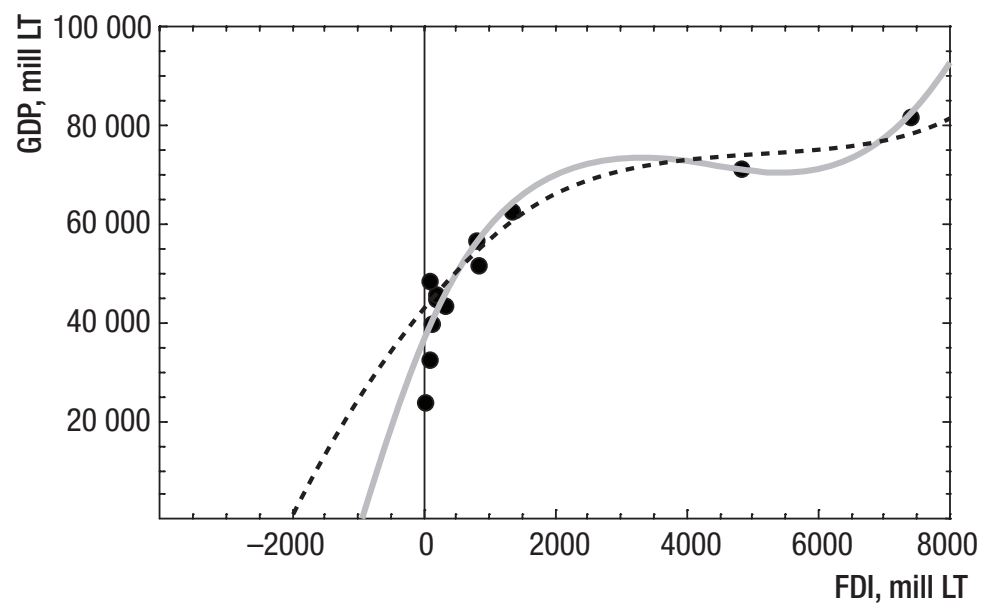

Fig. 3. Graphical view of non-linear relationship between GDP in manufacturing sector of refined petroleum and FDI directed into the economic activity

(two the nearest options presented) 
for longer period, then type of relationship between sector GDP and sector FDI does not change, principally, if FDI impact is considered for a part of initially taken time span. Economic interpretation could be put in the following way: FDI impact on development of economic activity does not change because of time lag, which may change conditions in which globalized companies operate.

Let us scrutinize manufacturing sector of textile using suggested theoretical framework. The non-linear relationship between FDI channelled into textile manufacturing industry and expansion of the industry, reflected by GDP generated in it, is being depicted by a curve, which differs from a straight (Fig. 2).

If theoretical framework is adopted, then assumption arises that after medium-term period FDI reaches industry, character of FDI impact on development of economic sector may change. Correlation coefficients for linear relationships for the 11-year period (1996-2007) and two compounding periods (1996-2002) and (2002-2007), respectively, are presented in Table 1. In this case rather a controversial situation has been revealed. If for all considered period correlation coefficient is 0.843 , for 1996-2002 it equals 0.909 . Correlation coefficient of linear relationship for the 2002-2007 period appears to change considerably not only in strength, but in direction as well, and shows a rather strong negative relationship, i.e. is equal to -0.735 . The obtained results serve as the most vivid illustration of a scale within which mathematical result, and, respectively economic interpretation of received quantitative evaluation can change, when for analysis purposes different time spans are being used. Intuition is, that the case presented above, represents situation, when after any form of globalization ("green field" investments or acquisitions) positive effects in form of any kinds of tacit spillovers have quantitatively measurable effects only in the medium-term period. Later, we think, due to the innovation absorptive capacity, industry structure, relationships with various market players and tilt in foreign capital stakeholders' interests, impact of globalization on development of local industry, plausibly, changes. Lithuanian textile manufacturing industry's case for 2002-2007 represents the case of oppositely changed FDI impact, as rather a strong negative interrelation between branch's GDP and cumulative FDI has appeared.

In order to approach at least tentative generalizations, let us take a closer look at another comprising economic activity of manufacturing industry branch, i.e. manufacturing sector of refined petroleum. According to suggested theoretical framework, the non-linear relationship between cumulative FDI and GDP statistically recorded in textile manufacturing industry during the 1996-2007 period has to be obtained. Curvilinear expression of the considered relationship is presented in Fig. 3. Shape of curve, reflecting nonlinear relationship comparing to a straight, visually seems remote.

According to assumption, incorporated into theoretical framework, it should signal that impact of FDI on development of economic activity changes after medium-term period, i.e. quantitatively estimated effect during the 11-year period (1996-2007) and compounding shorter 1996-2002 and 2002-2007 medium-term periods is different. Correlation coefficients of linear relationships (Table 1) indicate that in manufacturing sector of refined petroleum a rather strong positive relationship obtained for 1996-2007 (equalling to 0.701$)$ changes from very weak $(0.295)$ to weak $(0.480)$ if considered period is being split into two ones. These results, interpreted economically would mean 
that FDI, in that case, actually, has not contributed to development of manufacturing sector of refined petroleum. As we see, two insights from the obtained results might be drawn. The first, application of different economic phenomena's estimation modes in some cases can lead to differing conclusions; insight consistent with results received by application of other mathematical tools of economic analysis (Tvaronavičienè et al. 2008). The second insight contains a suggestion that more close surveillance of globalization outcomes after a certain time lag, which in our case embraces 6-7 years, has to be performed. Conditions, under which change of FDI impact on development of globalized economic branch shows up, remain the object of further elaboration.

\section{Conclusions}

In order to decide whether globalization in form of FDI enhances national wealth, an approach to evaluation and, consequently, theoretical framework of analysis has to be developed. In the presented paper elaboration of such framework is being based on an assumption that FDI affects national wealth through impact on the development of a particular branch of economy, which can appear to be within a wide range of values and reflect impact which varies from significantly positive to significantly negative. Further, assumption is being raised, that impact of FDI can change after medium-term period (of 6-7 years) passes. Whether the impact of FDI would change during the longer (11-year) period, under theoretical framework suggested, can be determined from the mathematical nature of the examined relationship (the relationship is calculated on the basis of GDP in the branch analysed and FDI in the branch).

If the non-linear relation for the considered (as it was mentioned above, in Lithuanian case it embraces 11 years) period is rather close to linear relation, it is assumed, that the mode of FDI impact on industry development most likely would remain not changed. If non-linear relation does not resemble linear, it is considered that the fact points of the shift in the direction of the relation change due to the changing impact of FDI on industry. In the latter case, i.e., in the next stage of analysis, the period under review is split into two: the stage of the intensive arrival of FDI, and the following stage.

FDI impact on the economic development of more economically developed countries differs from the impact of foreign capital on the economy of less-developed countries. After the average period of 6-7 years following the inflow of FDI into the host country due to change of companies structure in FDI receiving branches of host economy and due to other factors, such as fast absorption of spillover effects and, consequently, diminishing of FDI branch development enhancing power, domination of interests of repatriating profits, etc., strength of the FDI impact and even its trend may undergo certain changes. The analysis of the Lithuanian manufacturing branch revealed change of FDI impact on some manufacturing sectors' expansion: the initial positive impact of the foreign capital in some cases appeared to be unsustainable.

Case study of Lithuanian economy appeared to be consistent with suggested theoretical framework, which, as we see it, provides with new approaches to FDI cost benefit analysis, which we expect would trigger newly formulated scientific discussion about globalization consequences and, respectively, policy implications. 


\section{References}

Adekola, A.; Korsakiene, R.; Tvaronaviciene, M. 2008. Approach to innovative activities by Lithuanian companies in the current conditions of development, Technological and Economic Development of Economy 14(4): 595-611. doi:10.3846/1392-8619.2008.14.595-611

Borensztein, E.; De Gregorio, J.; Lee, J-W. 1998. How does foreign direct investment affect economic growth? Journal of International Economics 45(1): 115-135.

doi:10.1016/S0022-1996(97)00033-0

Buckley, P. J. 2006. Stephen Hymer: Three phases, one approach? International Business Review 15: 140-147. doi:10.1016/j.ibusrev.2005.03.008

Buckley, P. J.; Casson, M. 1998. Analyzing foreign market entry strategies: extending the internalization approach, Journal of International Business Studies 29(3): 539-561.

doi:10.1057/palgrave.jibs.8490006

Durham, J.; Benson, A. 2004. Economic growth and institutions: some sensitivity analyses, 1961-2000, International Organizations 58(3): 485-529. doi:10.1017/S0020818304583030

Ginevičius, R.; Tvaronavičiene, M. 2004. Risk of globalization: case study of Lithuanian economy, Ekonomický Časopis [Journal of Economics] 52(2): 212-231.

Goldstein, I; Assaf, R. 2006. An information-based trade off between foreign direct investment and foreign portfolio investment, Journal of International Economics 70(2): 271-295.

doi:10.1016/j.jinteco.2005.12.002

Hosseini, H. 2005. An economic theory of FDI: a behavioural economics and historical approach, The Journal of Socio-Economics 34: 528-541. doi:10.1016/j.socec.2005.07.001

Jensen, C. 2006. Foreign direct investment and economic transition: panacea or pain killer? Europe-Asia Studies 58(6): 881-902. doi:10.1080/09668130600831084

Kalašinskaite, K. 2009. Tiesioginiu užsienio investiciju poveikis ekonomikos plètrai Lietuvos ir kitu Baltijos šaliu pavyzdžiu [The impact of Foreign Direct Investment on economic development: case of Lithuania and other Baltic States]. Daktaro disertacija. Vinius: Technika. 112 p. (in Lithuanian).

Kenen, P. B. 2007. The benefits and risks of financial globalization, CATO Journal 27(2): 179-183.

Kottaridi, C. 2005. The 'Core-Periphery' pattern of FDI-led growth and production structure in the EU, Applied Economics 37(1): 99-113. doi:10.1080/0003684042000291308

Lapinskienè, G.; Tvaronavičienè, M. 2009. Sustainable development accross Central and Eastern Europe: key factors driving the economic growth of the countries, Verslas: teorija ir paktika [Business:Theory and Practice] 10(3): 204-213. doi:10.3846/1648-0627.2009.10.204-213

Leahy, D.; Montagna, C. 2000. Unionization and foreign direct investment: challenging conventional wisdom? Economic Journal 110(462): 80-92. doi:10.1111/1468-0297.00522

McClintock, B. 1988. Recent theories of direct foreign investment: an institutional perspective, Journal of Economic Issues 22(2): 477-485.

Meyer, K.; Saul, E. 2001. Brownfield entry in emerging markets, Journal of International Business Studies 32(3): 575-584. doi:10.1057/palgrave.jibs.8490985

Raff, H.; Ryan, M.; Stähler, F. 2009. The choice of market entry mode: greenfield investment, M\&A and joint venture, International Review of Economics and Finance 18(1): 3-10. doi:10.1016/j.iref.2008.02.006

Romer, P. 1993. Idea Gaps and object gaps in economic development, Journal of Monetary Economics 32(3): 543-573. doi:10.1016/0304-3932(93)90029-F

Romer, P. 1986. Increasing returns and long-run growth, Journal of Political Economy 94 (5): 1002-1037. doi:10.1086/261420 
Tarzi, S. 2005. Foreign Direct Investment flows into developing countries: impact of location and government policy, Journal of Social, Political \& Economic Studies 30(4): 497-515.

Tiiks, M. 2007. Technology-intensive FDI and economic development in a small country - the case of Estonia, A Journal of the Humanities \& Social Sciences 11(3): 324-342.

Tvaronavičienè, M.; Kalašinskaitè, K. 2007. Impact of foreign direct investments on Lithuanian banking sector, in 4th International Scientific Conference Business and Management and $14^{\text {th }}$ International Scientific Conference, Enterprise Management: Diagnosis, Strategy, Efficiency: Selected papers. 5-6 October, Vilnius, Lithuania. Vilnius: Technika, 81-89.

Tvaronavičienè, M.; Degutis, M. 2007. If approach to innovations differs in locally and foreign owned firms: case of Lithuania, Journal of Business Economics and Management 7(3): 195-203.

Tvaronavičienè, M.; Grybaitè, V. 2007. Impact of FDI on Lithuanian economy: insight into development of main economic activities, Journal of Business Economics and Management 8(4): $285-290$.

Tvaronavičienè, M.; Grybaitė, V.; Tvaronavičienè, A. 2009. If institutional performance matters: development comparisons of Lithuania, Latvia and Estonia, Journal of Business Economics and Management 10(3): 271-278. doi:10.3846/1611-1699.2009.10.271-278

Tvaronavičius, V.; Tvaronavičienè, M. 2008. Role of fixed investments in economic growth of country: Lithuania in European context, Journal of Business Economics and Management 9(1): 57-64. doi:10.3846/1611-1699.2008.9.57-64

\section{AR VISADA GLOBALIZACIJA, VYKSTANTI TIESIOGINIŲ UŽSIENIO INVESTICIJŲ FORMA, DIDINA NACIONALINI TURTĄ: LIETUVOS ATVEJIS}

\section{Tvaronavičienė, K. Kalašinskaitė}

\section{Santrauka}

Straipsnyje siūlomas originalus, teoriškai pagrịstas modelis, skirtas nustatyti, kaip laikui bėgant kinta tiesioginių užsienio investicijų (TUI) poveikis šalies šeimininkès ekonominiam vystymuisi. Autoriai, vertindami TUI poveiki, taiko sąnaudu ir naudos analizės principą. Kadangi valstybės politika, palanki užsienio investicijoms, dažniausia reiškia šalies sąnaudas joms pritraukti, kyla ekonominių instrumentų, reikalingų TUI ekonominiam naudingumui įvertinti, sukūrimo problema. Jai spręsti pasitelkiamos neoklasikinė ir industrinès organizacijos teorijos. Straipsnyje iškeliama ir tikrinama prielaida, kad TUI poveikis šalies šeimininkès ekonominiam vystymuisi pakinta po TUI atėjimo praejjus vidutiniam, t. y. 5-6 metų, laikotarpiui. Tirti naudojami 1996-2007 m. laikotarpio Lietuvos trijų pagrindiniu pramonès sektorių duomenys. Sukurto modelio taikymo rezultatai leidžia atskleisti nevienodą TUI poveiki skirtingiems ekonomikos sektoriams bei leidžia teigti, jog pradinis teigiamas TUI poveikis vietinès ekonomikos vystymuisi turi tendenciją mažèti po investavimo praèjus 5-6 metams.

Reikšminiai žodžiai: TUI, ekonominis augimas, Lietuva, teorinis modelis.

Manuela TVARONAVIČIENĖ. Prof., Dr, Department of Enterprise Economics and Management, Vilnius Gediminas Technical University (Lithuania). Qualification raise: IESE Business School, Spain, Politechnico di Milano, Italy, Harvard Business School, USA. Research interests: economic development, foreign direct investment, business environment.

Kristina KALAŠINSKAITĖ. PhD, Department of Enterprise Economics and Business Management, Vilnius Gediminas Technical University (Lithuania). Research interests: foreign direct investment (FDI) and their economical evaluation. 


\section{APPENDIX 1}

GDP generated in main branches of economy, cumulative FDI directed into main branches of economy and obtained correlation coefficients for the 1996-2007 period

\begin{tabular}{|c|c|c|c|c|c|c|c|c|}
\hline \multirow[b]{2}{*}{ Years } & \multicolumn{2}{|c|}{$\begin{array}{l}\text { Agricultural } \\
\text { branch }\end{array}$} & \multicolumn{2}{|c|}{ Manufacturing } & \multicolumn{2}{|c|}{ Construction } & \multicolumn{2}{|c|}{ Services } \\
\hline & 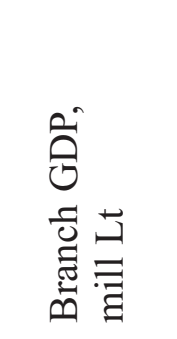 & 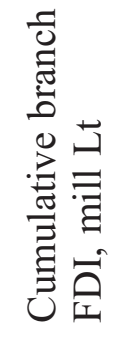 & 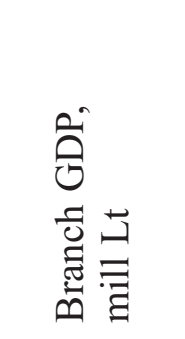 & 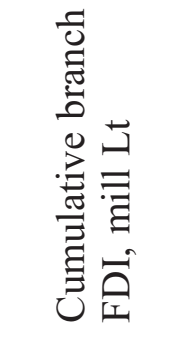 & 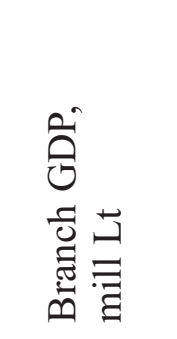 & 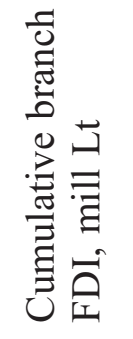 & 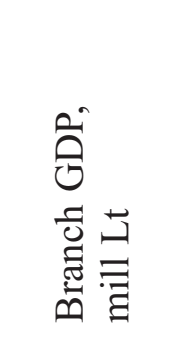 & 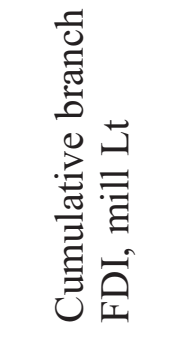 \\
\hline 1996 & 3661.80 & 18.40 & 5508.00 & 1153.19 & 2045.80 & 10.19 & 16610.10 & 1568.84 \\
\hline 1997 & 3990.90 & 49.23 & 6583.00 & 1524.93 & 2660.70 & 14.80 & 20124.00 & 2488.87 \\
\hline 1998 & 3832.30 & 55.91 & 7226.40 & 2106.06 & 3269.90 & 32.55 & 23036.20 & 4238.37 \\
\hline 1999 & 3201.70 & 41,80 & 6879.30 & 2625.08 & 2921.60 & 57,92 & 23536.00 & 5447.97 \\
\hline 2000 & 3188.60 & 44.86 & 7853.90 & 2686.00 & 2441.90 & 69.77 & 25255.90 & 6198.71 \\
\hline 2001 & 3055.10 & 50.60 & 8611.00 & 2728.66 & 2570.30 & 68.86 & 26882.80 & 7417.69 \\
\hline 2002 & 3247.50 & 60.87 & 8675.80 & 3863.64 & 2901.60 & 141.76 & 29199.20 & 8515.60 \\
\hline 2003 & 3265.90 & 111.74 & 9828.60 & 4260.18 & 3603.40 & 158.71 & 31466.10 & 8448.73 \\
\hline 2004 & 3308.10 & 127.77 & 11838.40 & 5503.20 & 4102.10 & 194.13 & 34523.00 & 9028.35 \\
\hline 2005 & 3661.70 & 168.10 & 13475.00 & 9457.60 & 4916.60 & 283.00 & 39501.50 & 10833.00 \\
\hline 2006 & 3807.00 & 170.30 & 15165.70 & 11510.30 & 6515.70 & 474.80 & 45142.30 & 13563.70 \\
\hline 2007 & 4593.20 & 192.13 & 16525.40 & 12570.90 & 8632.10 & 548.99 & 53129.00 & 17895.80 \\
\hline $\begin{array}{l}\mathrm{Co} \\
\mathrm{cos}\end{array}$ & $\begin{array}{l}\text { elation } \\
\text { fficient }\end{array}$ & 0.49 & & 0.98 & & 0.96 & & 0.98 \\
\hline
\end{tabular}




\section{APPENDIX 2}

Relationships in manufacturing branch between main manufacturing sectors GDP and FDI, when different time periods for analysis purposes are being used

\section{APPENDIX 2.1}

GDP generated in main branches of economy, cumulative FDI directed into main branches of economy and obtained correlation coefficients for the 1996-2007 period

\begin{tabular}{|c|c|c|c|c|c|c|}
\hline \multirow[b]{2}{*}{ Years } & \multicolumn{2}{|c|}{$\begin{array}{l}\text { Manufacturing sector } \\
\text { of food products }\end{array}$} & \multicolumn{2}{|c|}{$\begin{array}{l}\text { Manufacturing sector } \\
\text { of textile }\end{array}$} & \multicolumn{2}{|c|}{$\begin{array}{l}\text { Manufacturing sector } \\
\text { of refined petroleum }\end{array}$} \\
\hline & 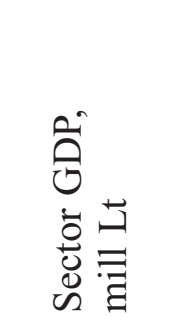 & 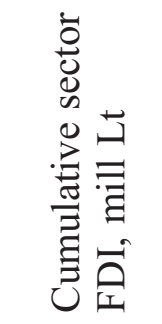 & 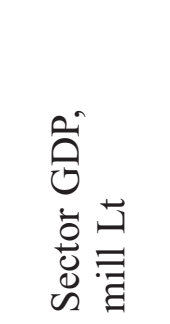 & 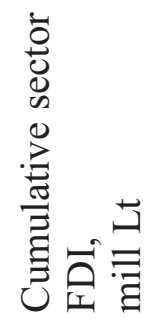 & 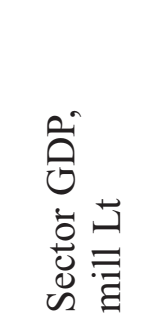 & 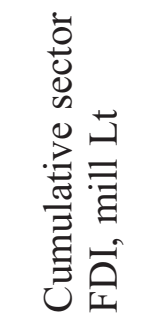 \\
\hline 1996 & 1700.60 & 452.22 & 904.20 & 160.43 & 362.60 & 69.01 \\
\hline 1997 & 1891.30 & 555.95 & 1077.90 & 133.86 & 610.60 & 107.55 \\
\hline 1998 & 1935.10 & 764.78 & 1247.60 & 263.58 & 519.20 & 197.45 \\
\hline 1999 & 1722.30 & 973.96 & 1308.30 & 289.54 & 410.00 & 303.02 \\
\hline 2000 & 1809.00 & 1077.25 & 1426.50 & 351.41 & 760.90 & 171.16 \\
\hline 2001 & 1919.30 & 1157.06 & 1569.80 & 334.17 & 917.50 & 92.65 \\
\hline 2002 & 1863.10 & 1480.63 & 1486.30 & 309.57 & 805.70 & 821.82 \\
\hline 2003 & 1982.20 & 1602.02 & 1477.80 & 303.38 & 927.40 & 779.76 \\
\hline 2004 & 2178.60 & 1670.08 & 1587.40 & 262.96 & 1367.60 & 1327.82 \\
\hline 2005 & 2453.50 & 1618.50 & 1506.80 & 326.90 & 1801.20 & 4820.00 \\
\hline 2006 & 2761.10 & 1433.90 & 1524.10 & 315.88 & 1631.10 & 7386.80 \\
\hline 2007 & 3479.90 & 1522.58 & 1477.50 & 310.38 & 1085.90 & 8097.19 \\
\hline Corre & n coefficie & 0.529 & & 0.843 & & 0.701 \\
\hline
\end{tabular}




\section{APPENDIX 2.2}

GDP generated in main branches of economy, cumulative FDI directed into main branches of economy and obtained correlation coefficients for the 1996-2002 period

\begin{tabular}{ccccccc}
\hline & \multicolumn{2}{c}{$\begin{array}{c}\text { Manufacturing sector } \\
\text { of food products }\end{array}$} & \multicolumn{2}{c}{$\begin{array}{c}\text { Manufacturing sector } \\
\text { of textile }\end{array}$} & \multicolumn{2}{c}{$\begin{array}{c}\text { Manufacturing sector } \\
\text { of refined petroleum }\end{array}$} \\
\cline { 2 - 7 } & $\begin{array}{c}\text { Sector GDP, } \\
\text { mill Lt }\end{array}$ & $\begin{array}{c}\text { Cumulative } \\
\text { sector } \\
\text { FDI, } \\
\text { mill Lt }\end{array}$ & $\begin{array}{c}\text { Sector GDP, } \\
\text { mill Lt }\end{array}$ & $\begin{array}{c}\text { Cumulative } \\
\text { sector } \\
\text { FDI, } \\
\text { mill Lt }\end{array}$ & $\begin{array}{c}\text { Sector GDP, } \\
\text { mill Lt }\end{array}$ & $\begin{array}{c}\text { Cumulative } \\
\text { sector } \\
\text { FDI, } \\
\text { mill Lt }\end{array}$ \\
\hline 1996 & 1700.60 & 452.22 & 904.20 & 160.43 & 362.60 & 69.01 \\
\hline 1997 & 1891.30 & 555.95 & 1077.90 & 133.86 & 610.60 & 107.55 \\
\hline 1998 & 1935.10 & 764.78 & 1247.60 & 263.58 & 519.20 & 197.45 \\
\hline 1999 & 1722.30 & 973.96 & 1308.30 & 289.54 & 410.00 & 303.02 \\
\hline 2000 & 1809.00 & 1077.25 & 1426.50 & 351.41 & 760.90 & 171.16 \\
\hline 2001 & 1919.30 & 1157.06 & 1569.80 & 334.17 & 917.50 & 92.65 \\
\hline 2002 & 1863.10 & 1480.63 & 1486.30 & $309, .57$ & 820.60 & 821.82 \\
\hline \multicolumn{2}{c}{ Correlation } & 0.260 & & 0.909 & & 0.295 \\
\hline coefficient & & & & & \\
\hline
\end{tabular}

\section{APPENDIX 2.3}

GDP generated in main branches of economy, cumulative FDI directed into main branches of economy and obtained correlation coefficients for the 2002-2007 period

\begin{tabular}{ccccccc}
\hline Years & \multicolumn{2}{c}{$\begin{array}{c}\text { Manufacturing sector of } \\
\text { food products }\end{array}$} & \multicolumn{2}{c}{$\begin{array}{c}\text { Manufacturing sector of } \\
\text { textile }\end{array}$} & \multicolumn{2}{c}{$\begin{array}{c}\text { Manufacturing sector of } \\
\text { refined petroleum }\end{array}$} \\
\cline { 2 - 8 } & $\begin{array}{c}\text { Cumulative } \\
\text { sector } \\
\text { FDI, } \\
\text { mill Lt }\end{array}$ & $\begin{array}{c}\text { Sector GDP, } \\
\text { mill Lt }\end{array}$ & $\begin{array}{c}\text { Cumulative } \\
\text { sector } \\
\text { FDI, } \\
\text { mill Lt }\end{array}$ & $\begin{array}{c}\text { Sector GDP, } \\
\text { mill Lt }\end{array}$ & $\begin{array}{c}\text { Cumulative } \\
\text { sector } \\
\text { FDI, } \\
\text { mill Lt }\end{array}$ & $\begin{array}{c}\text { Sector GDP, } \\
\text { mill Lt }\end{array}$ \\
\hline 2002 & 1863.10 & 1480.63 & 1486.30 & 309.57 & 820.60 & 821.82 \\
\hline 2003 & 1982.20 & 1602.02 & 1477.80 & 303.38 & 927.40 & 779.76 \\
\hline 2004 & 2178.60 & 1670.08 & 1587.40 & 262.96 & 1367.60 & 1327.82 \\
\hline 2005 & 2453.50 & 1618.50 & 1506.80 & 326.90 & 1801.20 & 4820.00 \\
\hline 2006 & 2761.10 & 1433.90 & 1524.10 & 315.88 & 1631.10 & 7386.80 \\
\hline 2007 & 3479.90 & 1522.58 & 1477.50 & 310.38 & 1085.90 & 8097.19 \\
\hline \multicolumn{2}{c}{$\begin{array}{c}\text { Correlation } \\
\text { coefficient }\end{array}$} & -0.297 & & -0.735 & & 0.480 \\
\hline
\end{tabular}

